\title{
Competitiveness Model and Gap Analysis of Indonesian Palm Oil-Based Fatty Acid and Fatty Alcohol Industry
}

\author{
Toni Yoyo ${ }^{1}$, Arief Daryanto ${ }^{1}$, Endang Gumbira-Sa'id ${ }^{1} \&$ Mohamad Fadhil Hasan $^{1}$ \\ ${ }^{1}$ Graduate School of Management and Business, Bogor Agricultural University, Indonesia \\ Correspondence: Toni Yoyo, Graduate School of Management and Business, Bogor Agricultural University, Jl. \\ Padjajaran, Bogor, Indonesia. Tel: 62-816-1128-455. E-mail: toni_yoyo@yahoo.com
}

Received: November 20, 2013

Accepted: December 16, $2013 \quad$ Online Published: January 23, 2014

doi:10.5539/ijef.v6n2p218

URL: http://dx.doi.org/10.5539/ijef.v6n2p218

\begin{abstract}
Oleochemicals can be derived from natural oils or fats. Palm oil-based fatty acids and fatty alcohols are the most important oleochemicals. The aims of this study are to develop a competitiveness model of Indonesian palm oil-based fatty acid and fatty alcohol industry, and to analyze the gap between the current and ideal (future) conditions of the industry, using competitiveness framework being developed by the International Institute for Management Development (IMD). This study used literature review, in-depth interview, and questionnaire method to gather opinions from the experts and/or practitioners of the industry of the current and ideal (future) conditions. The non-parametric Mann-Whitney test is used to assess the differences between both conditions. The results of this study show that the biggest gap using IMD competitiveness framework is government efficiency while the smallest gap is business efficiency. The results of this study also show significant differences between the current and ideal (future) conditions of the industry at $\alpha=5 \%$ for all factors and total IMD competitiveness. Only two sub-factors have no significant difference, namely employment and prices. The competitiveness improvement of the industry has to involve all stakeholders by resolving existing problems in systemic and systematic approaches.
\end{abstract}

Keywords: competitiveness, experts, practitioners, fatty acids, fatty alcohols, gap analysis

\section{Introduction}

Oleochemicals are chemicals derived from natural oils or fats (from plants or animals). Basic oleochemicals consist of fatty acids, fatty alcohols, methyl esters, fatty amines, and glycerol (Ong et al., 1989). Derivative products of oleochemicals are soaps, detergents, surfactants, metallic soaps, plastic and rubber products, candles and crayons, cosmetic, toiletries, synthetic lubricant and cutting oils, food emulsifiers, pharmaceuticals, varnished and paint, etc. Raw materials being used in the production of oleochemicals are tallow, stearin, and lauric oils (LMC International, 2009). Stearin is a derivative of crude palm oil (CPO). One example of lauric oil is crude palm kernel oil (CPKO) for its high lauric acid content.

World demand on oleochemicals has increased each year. The increasing world demand has been due to increasing application of oleochemicals in a wide variety of daily needs products, increasing number of world population, rising number of middle class population, and increasing income per capita in many countries. The increasing world demand on oleochemicals has also been boosted by the advantages of oleochemicals over petrochemicals (chemicals derived from petroleum), such as lower prices, derived from renewable sources, and more environmentally friendly. This study focuses on the Indonesian palm oil-based fatty acid and fatty alcohol industry as the most important basic oleochemicals, and the fact that Indonesia is the largest CPO and CPKO producer in the world.

Even though Indonesia has strong point of raw material abundance of fatty acids and fatty alcohols, Indonesian production of palm oil-based fatty acids and fatty alcohols are less than Malaysia. Indonesia exports more CPO and CPKO whereas Malaysia mainly exports CPO and CPKO derivative products including palm oil-based fatty acids and fatty alcohols. The importing countries of Indonesian CPO and CPKO, such as India and China, are more advance in the development of palm oil-based fatty acid and fatty alcohol industries.

Porter $(1990,1998)$ developed a competitiveness cluster model (well known as diamond clusters) to create a competitive advantage consisting of six factors, namely factor conditions, demand conditions, firm strategy, structure, and rivalry, related and supporting industries, government, and chance. Government can influence the 
other factors except chance. Chance events occur beyond the control of the industry and are important in creating discontinuities.

Discussion on nation competitiveness is generally focused on economic performance as measured by gross domestic product (GDP) per capita (productivity) and trade performance. Nation competitiveness is the set of factors, policies, and institutions that affect the level of productivity of a country (WEF, 2009). Scientific approach for the measurement and analysis of competitiveness can be done by qualitative and quantitative approaches (Zhang et al., 2009), namely modeling approach, indicator approach (Esterhuizen, 2006; Zhang et al., 2009), and weighted sum approach (Zhang et al., 2009).

Weighted sum approaches are done by developing key competitiveness indices consisting of a number of indicators using certain weighting method. Measuring competitiveness index using weighted sum approach has been widely used in the competitiveness reports of various countries in the world being developed by the International Institute for Management Development (IMD, 2009). IMD uses four factors of competitiveness (competitiveness cube), namely government efficiency, business efficiency, economic performance, and infrastructure. Each factor consists of five sub-factors resulted in a total of 20 sub-factors (IMD, 2009).

Competitive advantage analysis of palm oil-based products, such as oleochemicals in Indonesia was carried out by Usman (2003). The method being used was descriptive method with a case study approach and a survey on the performance and the existence of palm oil-based oleochemical industry in Indonesia. On the other hand, Pahan (2011) conducted a study regarding the development of Indonesian palm oil industrial cluster using hybrid strategic approaches which were industrial organization (IO) theory and resource-based view (RBV) theory. The aim of the study was to develop future palm oil industrial cluster with Indonesia economy and business environment constraints. The study used analytic network process (ANP) and descriptive analysis to assess the performance of Indonesian palm oil industrial cluster. Liwang (2011) conducted a study to analyze the dynamics of oil palm seed market in Indonesia. The study used descriptive analysis, Pearson's correlation analysis, diagonal split analysis, Thurstone analysis, and ANP.

Researches on the behavior of Indonesian palm oil industry and its impact had been conducted by several researchers, among others were Said-Didu (2000) on the design of decision support system for the development of Indonesian palm agro-industry, Sugiyanto (2002) on the effect of liberalization of Indonesian palm oil market, and Chalil (2008) on the impact of asymmetric duopoly in Indonesian palm oil industry. Researches on the competitiveness of several Indonesian main commodities, including palm oil, had been done by several researchers. Simanjuntak (1992) examined the factors affecting the competitiveness of Indonesian palm oil. A similar study conducted by Vidyatmoko and Zubair (2002) using a competitive model of Porter Diamond was to analyze the factors affecting palm oil supply and demand in Indonesia and the world.

Previous studies on the competitiveness of other Indonesian agricultural products, among others were: Sandaya (1998) for fisheries, Daryanto (2007) for cocoa, Wartono (1999) for cashew, Sukmawati (1999) for processed milk, Rosadi (2002) for forestry products, such as pulp and paper, Suprihatini (2005) for tea, Hallat (2005) for oil seeds, such as sunflower seeds and peanuts, Muslim (2006) for coconut, Darmayanti (2007) for nutmeg, and Daryanto (2007, 2009) for the livestock industry.

Based on the previous studies, it can be concluded that researches on palm oil industry and market mainly focused on oil palm-related products, such as fresh fruit bunches (FFB), CPO, palm oil-based products (derivatives), and very rare on fatty acids and fatty alcohols. Generally, competitiveness analysis tools being used, in the previous studies, were Porter Five Forces Model, Porter Diamond, Nine Factors-Model Competitiveness, or combination with other analytic tools, however none of them using competitiveness framework being developed by IMD. Therefore, this study becomes unique by focusing on the competitiveness determinants of Indonesian palm oil-based fatty acid and fatty alcohol industry. This study also becomes unique by examining and analyzing the gap between the current and ideal (future) conditions of the industry, using competitiveness framework being developed by IMD.

The aim of this study is to identify and examine the factors affecting the performance of Indonesian palm oil-based fatty acid and fatty alcohol industry, and to develop a competitiveness model of the industry. In addition, this study is also to analyze the gap between the current and ideal (future) conditions of the industry.

The rest of the paper will be organized as follows: after introduction, we describe the methodology and data in Section 2, being followed by results and discussion in Section 3. Finally, Section 4 gives summary and conclusion remarks. 


\section{Methodology, Variable and Data}

\subsection{Methodology}

The competitiveness model of Indonesian palm oil-based fatty acid and fatty alcohol industry was carried out through intensive literature studies. The competitiveness model is developed to confirm factors affecting performance of the industry based on Industrial Organization (IO) theory, especially the Porter Diamond concept.

This study used in-depth interview and questionnaire (based on Likert scale of 1-9) methods to gather opinions from the experts and/or practitioners of the current and ideal (future) conditions of the industry. Questionnaire was developed using competitiveness framework being developed by IMD.

This study then uses non-parametric Mann-Whitney test to assess the differences between the current and ideal (future) conditions of the industry. The $\mathrm{H}_{0}$ (null hypothesis) is there is no difference between the current and ideal (future) conditions of the industry at $\alpha=5 \%$. By interpretation of the $p$-value generated from Minitab 16.0, if $p$-value exceeds 0.05 ( $\mathrm{p}$-value $>0.05$ ), then accept the null hypothesis and declare that there is no difference between the two conditions. On the other hand, if $p$-value smaller than or equal to 0.05 (p-value $<=0.05$ ), then reject the null hypothesis and declare that there is significant difference between the two conditions.

\subsection{Variables and Measurement}

Measurements of research variables are conducted using expert and/or practitioner opinions (15 respondents) which were selected using purposive sampling method from the supply chain of Indonesian palm oil-based fatty acid and fatty alcohol industry for the current and ideal (future) conditions of the industry. In general, the ideal condition will take at least 10 years from now (Pahan, 2011).

\subsection{Data}

The primary data of this study are the opinions (based on Likert scale of 1-9) of Indonesian palm oil-based fatty acid and fatty alcohol industry experts and/or practitioners for the current and ideal (future) conditions of the industry. The primary data are a cross sectional type of data. All the expert and/or practitioner opinions are arranged in a table and arithmetic means are calculated. Then the gaps between the current and ideal (future) conditions of the industry for all sub-factors, factors, and total factor are calculated. Finally, the non-parametric Mann-Whitney tests are used to assess medians of each sub-factor for the two conditions whether the differences between the current and ideal (future) conditions of the industry are significant or not at $\alpha=5 \%$.

\section{Results and Discussion}

\subsection{Competitiveness Model of Indonesian Palm Oil-Based Fatty Acid and Fatty Alcohol Industry}

Performance of Indonesian palm oil-based fatty acid and fatty alcohol industry is determined by the competitiveness of this industry in domestic market as well as in global market. Adapting the Porter Diamond concept, competitiveness of the industry is influenced by six factors factors, namely factor conditions, demand conditions, firm strategy, structure, and rivalry, related and supporting industries, government, and chance. Each factor consists of several sub-factors, which are interrelated, interacted, and influenced each other.

Factor conditions in the competitiveness model of Indonesian palm oil-based fatty acid and fatty alcohol industry cover both internal and external factors. Demand conditions in the home market help companies to create a competitive advantage, when sophisticated home market buyers pressure firms to innovate faster and to create more advanced products than those of competitors. Firm strategy, structure and rivalry mean the way in which companies are created, set goals and managed. The presence of intense rivalry in the home base is important to create pressure to innovate in order to upgrade competitiveness. Related and supporting industries provide cost-effective inputs and also participate in the upgrading process, thus stimulate other companies in the chain to innovate. Government is the regulator issuing various policies and regulations and ensuring the implementation of those policies and regulations. The sub-factors within each factor of these five factors affect each other and among the five factors also influence and interact each other. Chance is the only factor that affects the other five factors but very little or almost none being affected by the other five factors.

According to the competitiveness model of Indonesian palm oil-based fatty acid and fatty alcohol industry which is developed using Porter competitiveness cluster model (diamond clusters), there are some sub-factors whose status of 'good' and the other sub-factors are still at 'poor' status. The 'poor' sub-factors apparently are weaknesses and must be improved as soon as possible. The competitiveness model of the industry is shown in Figure 1. Notation ' + ' (plus) means strong point reflecting good status of current condition. On the other hand, notation '-' (minus) means weak point reflecting poor or below standard status of current condition. Minus points should be resolved or enhanced to improve the competitiveness of the industry in the future. 


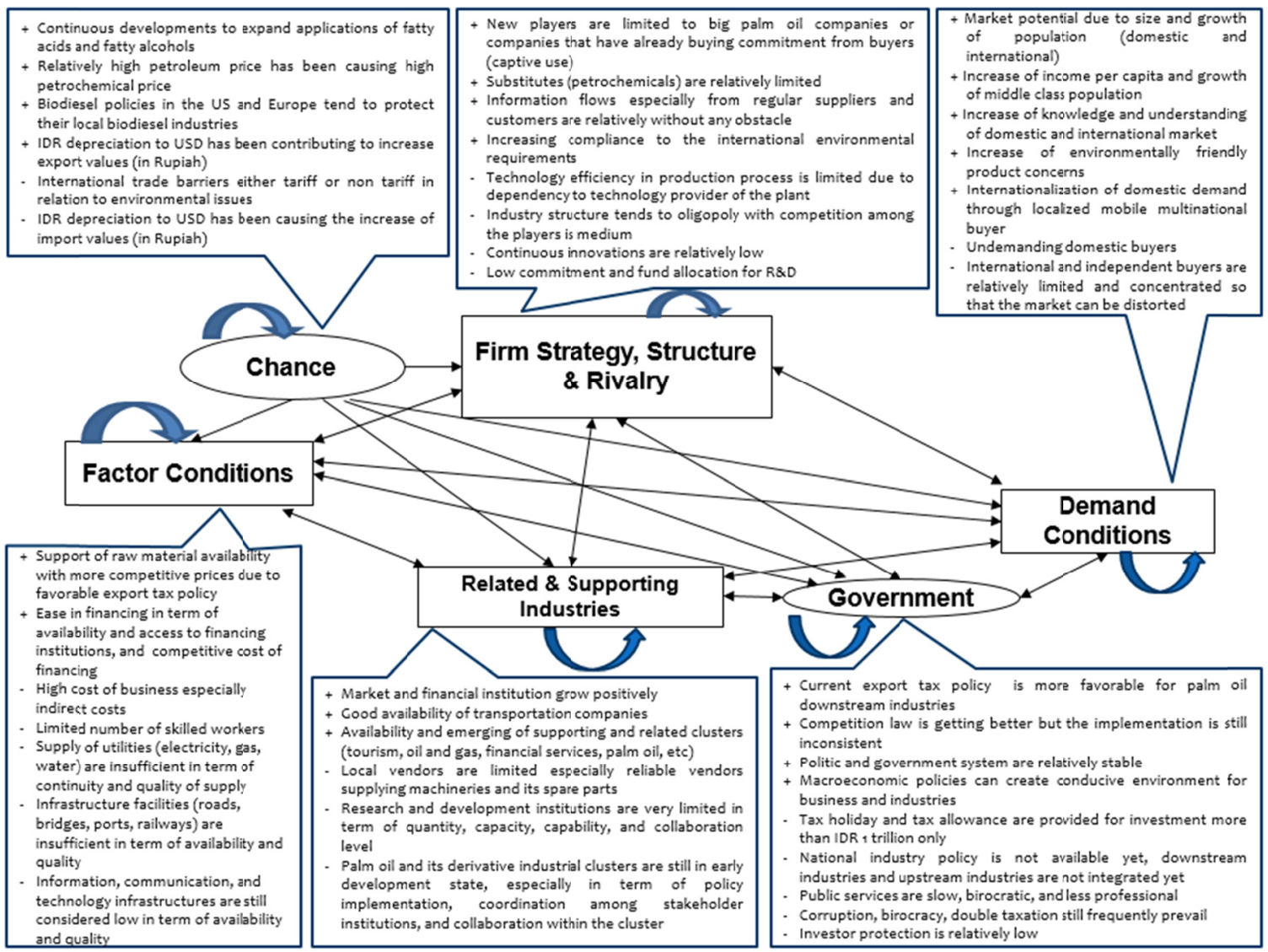

Figure 1. Competitiveness model of Indonesian palm oil-based fatty acid and fatty alcohol industry

Note: '+' means 'strength' and '-' means 'weakness'.

\subsection{Gap Analysis Using IMD Competitiveness Framework}

This new era of information and various forms of global competition flowing in all directions creating an environment that is more complex, turbulent, contradictory, inconsistent, and multi-dimensional (Zuhal, 2010). Development of Indonesian palm oil-based fatty acid and fatty alcohol industry must be able to respond to external changes correctly, quickly, and efficiently to achieve sustainable competitive advantage. The purpose of this study gathered the opinions of the industry experts and/or practitioners for the current and ideal (future) conditions of the industry was to elicit tacit knowledge into explicit knowledge.

Table 1 and Figure 2 show the arithmetic means of all the expert and/or practitioner opinions for the current and ideal (future) conditions of the industry. The current condition of all sub-factors of IMD competitiveness framework are below the ideal (future) condition. From a total of 20 sub-factors, the sub-factor with the biggest gap (57.55\%) is public finance. This means that current public finance-related items have to be increased by $57.55 \%$ to reach the ideal conditions in the future. The sub-factor that has the smallest gap (5.33\%) is employment. This is a result of utilizing industry's latest and advanced technology, which does not require lots of manpower, currently nor in the future.

The sub-factor for the current condition that has the lowest score (3.00) is public finance. This means that budget allocation for construction and maintenance of public facilities such as infrastructure, and research and development are considered poor. The sub-factor for the current condition that has the highest score (6.87) is productivity. This means that production efficiency of the industry is considered good enough due to utilization of latest and advanced technology.

On the other hand, the sub-factor for the ideal (future) condition that has the lowest score (4.47) is prices. This means that in the future, contribution to inflation of palm oil-based fatty acid and fatty alcohol prices in Indonesia is considered relatively stable as at current condition since the prices of the products have no direct influence on inflation. The sub-factor for the ideal (future) condition that has the highest score (7.93) is productivity. This 
means that in the future, production is expected to be more efficient by adopting latest and advanced technology providing improvement especially in the production process. The productivity is reflected by the output of production of palm oil-based fatty acids and fatty alcohols divided by production factors (raw materials, labors, and money). The productivity also demonstrates the added value of the industry.

Table 1. IMD gap analysis per sub-factor

\begin{tabular}{lccc}
\hline \multicolumn{1}{c}{ Factor and Sub-Factor } & Current & Future & Gap \\
\hline Economic Performance: & & & \\
Domestic economy & 5.80 & 7.73 & $25.00 \%$ \\
International trade & 5.27 & 7.60 & $30.70 \%$ \\
International investment & 5.40 & 7.13 & $24.30 \%$ \\
Employment & 4.73 & 5.00 & $5.33 \%$ \\
Prices & 4.20 & 4.47 & $5.97 \%$ \\
\hline Government Efficiency: & & & \\
Public finance & 3.00 & 7.07 & $57.55 \%$ \\
Fiscal policy & 5.87 & 7.13 & $17.76 \%$ \\
Institutional framework & 3.60 & 6.80 & $47.06 \%$ \\
Business legislation & 4.47 & 6.93 & $35.58 \%$ \\
Societal framework & 5.27 & 7.07 & $25.47 \%$ \\
\hline Business Efficiency: & & & \\
Productivity & 6.87 & 7.93 & $13.45 \%$ \\
Labor market & 5.27 & 7.13 & $26.17 \%$ \\
Finance & 5.53 & 7.40 & $25.23 \%$ \\
Management practices & 6.40 & 7.73 & $17.24 \%$ \\
Attitudes and values & 6.27 & 7.60 & $17.54 \%$ \\
\hline Infrastructure: & & & \\
Basic infrastructure & 3.33 & 7.47 & $55.36 \%$ \\
Technological infrastructure & 6.33 & 7.47 & $15.18 \%$ \\
Scientific infrastructure & 3.93 & 7.13 & $44.86 \%$ \\
Health and environment & 5.73 & 7.40 & $22.52 \%$ \\
Education & 4.87 & 7.33 & $33.64 \%$ \\
\hline
\end{tabular}

Scores: $1=$ extremely poor, $2=$ very poor, $3=$ =poor, $4=$ =nearly poor, $5=$ average, $6=$ nearly good, $7=$ good, $8=$ very good, $9=$ extremely good.

Source: Adapted from IMD (2009).

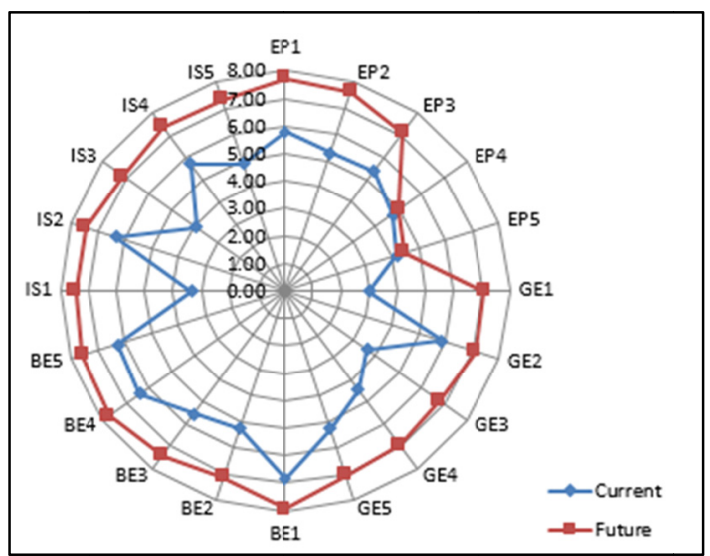

Figure 2. IMD gap analysis per sub-factor

Scores: $1=$ extremely poor, $2=$ very poor, $3=$ =poor, $4=$ =nearly poor, $5=$ average, $6=$ nearly good, $7=$ good, $8=$ very good, $9=$ extremely good.

Notation: EP1=Domestic economy, EP2=International trade, EP3=International investment, EP4=Employment, EP5=Prices, GEl=Public finance, GE2=Fiscal policy, GE3=Institutional framework, GE4=Business legislation, GE5=Societal framework, BE1=Productivity, $\mathrm{BE} 2=$ Labor market, BE3=Finance, BE4=Management practices, BE5=Attitudes and values, IS1=Basic infrastructure, IS2=Technological infrastructure, IS3=Scientific infrastructure, IS4=Health and environment, IS5=Education.

Source: Adapted from IMD (2009). 
Table 2 shows the gap analysis by factor and total factors. Government efficiency is the factor that has the biggest gap and is also perceived as the lowest current condition of the industry. On the other hand, business efficiency is the factor that has the smallest gap and is also perceived as the highest current condition of the industry. The gap for total factors is about $28 \%$. It means that the current overall condition of the industry toward a highly competitive industry in the ideal condition is only $72 \%$.

The competitiveness improvement of the industry is inevitably the obligation of all stakeholders by resolving existing problems so that the gap between the current and ideal conditions in the future could be minimized or eliminated. Management of competitiveness should be both systemic and systematic. "Systemic" means that the interaction between the factors of competitiveness is as important as the analysis of the factors themselves. For example, when focusing on developing infrastructure, it is not just about building airports, railroads, railways, ports, etc. It is also about connecting all these facilities into one integrated value-added logistical system based on the most modern technologies. On the other hand, "systematic" means that a competitiveness strategy needs to be coherent over time. Business is pretty adaptive to the most adverse conditions provided that the rules are clearly defined and predictable (Garelli, 2008).

Table 2. Arithmetic means and standard deviations of IMD gap analysis per factor

\begin{tabular}{lccccc}
\hline \multirow{2}{*}{$\begin{array}{c}\text { Competitiveness Factor } \\
\text { (IMD) }\end{array}$} & \multicolumn{3}{c}{ Arithmetic Mean (1-9) } & \multicolumn{2}{c}{ Standard Deviation } \\
\cline { 2 - 6 } & Current & Future & Gap & Current & Future \\
\hline Economic Performance & 5.08 & 6.39 & $20.46 \%$ & 0.62 & 1.54 \\
Government Efficiency & 4.44 & 7.00 & $36.57 \%$ & 1.17 & 0.13 \\
Business Efficiency & 6.07 & 7.56 & $19.75 \%$ & 0.65 & 0.31 \\
Infrastructure & 4.84 & 7.36 & $34.24 \%$ & 1.24 & 0.14 \\
Total & 5.11 & 7.08 & $27.84 \%$ & & \\
\hline
\end{tabular}

Scores: $1=$ extremely poor, $2=$ very poor, $3=$ poor, $4=$ nearly poor, $5=$ average, $6=$ nearly good, $7=$ good, $8=$ very good, $9=$ extremely good.

Source: Adapted from IMD (2009).

\subsection{Gap Analysis Using the Non-Parametric Mann-Whitney Test}

The non-parametric Mann-Whitney tests in this study focus on the differences between the current and ideal (future) conditions of Indonesian palm oil-based fatty acid and fatty alcohol industry. Mann-Whitney test is an alternative testing to the $t$ test without any restriction. This test can also be applied for a different number of samples tested in the two groups.

Table 3 shows medians of the current and ideal (future) conditions of the industry and p-values for sub-factors, factors, and total IMD competitiveness. It can be declared that only two sub-factors have no significant difference between the current and ideal (future) conditions of the industry at $\alpha=5 \%$, namely employment (contribution to provide employment) and prices (contribution to inflation) since the p-values are exceed 0.05 (accept null hypothesis). For factors and total IMD competitiveness, it can be declared that there are significant differences between the current and ideal (future) conditions of the industry at $\alpha=5 \%$ since the $\mathrm{p}$-values are smaller than 0.05 (reject null hypothesis).

Table 3. The non-parametric Mann-Whitney test results

\begin{tabular}{cccc}
\hline Factor and Sub-Factor & \multicolumn{2}{c}{ Score-Median } & Mann-Whitney \\
& Current & Future & p-value \\
\hline Economic Performance: & 5.00 & 7.00 & $0.0005^{*}$ \\
Domestic economy & 6.00 & 7.00 & $0.0011 *$ \\
International trade & 5.00 & 8.00 & $0.000 *^{*}$ \\
International investment & 5.00 & 7.00 & $0.0068 *$ \\
Employment & 5.00 & 5.00 & $0.3468 * *$ \\
Prices & 4.00 & 4.00 & $0.2277 * *$ \\
Government Efficiency: & 5.00 & 7.00 & $0.0000 *$ \\
Public finance & 3.00 & 7.00 & $0.0008^{*}$ \\
Fiscal policy & 6.00 & 7.00 & $0.0081 *$ \\
Institutional framework & 3.00 & 7.00 & $0.0000 *$ \\
Business legislation & 5.00 & 7.00 & $0.0000 *$ \\
Societal framework & 5.00 & 7.00 & $0.0000 *$ \\
Business Efficiency: & 6.00 & 8.00 & $0.0001 *$ \\
Productivity & 7.00 & 8.00 & $0.0000 *$ \\
\hline
\end{tabular}




\begin{tabular}{llll}
\hline Labor market & 5.00 & 7.00 & $0.000 *^{*}$ \\
Finance & 5.00 & 8.00 & $0.0001 *$ \\
Management practices & 7.00 & 8.00 & $0.000 *^{*}$ \\
Attitudes and values & 6.00 & 8.00 & $0.0001 *$ \\
Infrastructure: & 5.00 & 7.00 & $0.000 *^{*}$ \\
Basic infrastructure & 3.00 & 7.00 & $0.000 *^{*}$ \\
Technological infrastructure & 7.00 & 7.00 & $0.0014 *$ \\
Scientific infrastructure & 4.00 & 7.00 & $0.0000 *$ \\
Health and environment & 6.00 & 7.00 & $0.0002 *$ \\
Education & 5.00 & 7.00 & $0.0000 *$ \\
Total & 5.00 & 7.00 & $0.0000 *$ \\
\hline
\end{tabular}

Scores: $1=$ extremely poor, $2=$ very poor, $3=$ poor, $4=$ nearly poor, $5=$ average, $6=$ nearly good, $7=$ good, $8=$ very good, $9=$ extremely good.

Note: $*$ Significant differences at $\alpha=5 \%$, ** No significant differences at $\alpha=5 \%$.

\section{Conclusion}

Competitiveness of Indonesian palm oil-based fatty acid and fatty alcohol industry is influenced by six factors, namely factor conditions, demand conditions, firm strategy, structure, and rivalry, related and supporting industries, government, and chance. Each factor consists of several sub-factors, which are interrelated, interacted, and influenced each other. The results of this study show that according to the competitiveness model of the industry, there are some sub-factors with 'good' status and other sub-factors with 'poor' status. The 'poor' sub-factors apparently are weaknesses and must be improved.

The results of this study also show that the biggest gap between the current and ideal (future) conditions of the industry, using IMD competitiveness framework is government efficiency while the smallest gap is business efficiency. The other results of this study show that the gap for total factors using IMD competitiveness framework is about $28 \%$. It means that the current overall condition of the industry toward a highly competitive industry in the ideal condition is only $72 \%$. Moreover, the non-parametric Mann-Whitney test results show that there are significant differences between the current and ideal (future) conditions of the industry at $\alpha=5 \%$ for all factors and total IMD competitiveness. For sub-factors, only two sub-factors have no significant difference, namely employment and prices.

The competitiveness improvement of the industry has to involve all the stakeholders by resolving existing problems in systemic and systematic approaches. Further study is required to provide solutions to improve the status of the industry and minimize the gap between the current and ideal (future) conditions of Indonesian palm oil-based fatty acid and fatty alcohol industry.

\section{References}

Chalil, D. (2008). An empirical analysis of asymmetric duopoly in the Indonesian crude palm oil industry. Agricultural and Resource Economics Faculty of Agriculture, Food and Natural Resources, The University of Sydney, New South Wales. Retrieved from http://hdl.handle.net/2123/2566

Darmayanti, D. (2007). Strategy improving competitiveness of Indonesian nutmeg. Unpublished Thesis. Bogor Agricultural University, Bogor.

Daryanto. (2007). Competitiveness analysis of Indonesian cocoa in the international market. Unpublished Thesis. Bogor Agricultural University, Bogor.

Daryanto, A. (2007). Improving competitiveness of Indonesian poultry industry. PT Permata Wacana Lestari, Jakarta.

Daryanto, A. (2009). Competitiveness dynamics of Indonesian poultry industry. Bogor: IPB Press.

Esterhuizen, D. (2006). An evaluation of the competitiveness of the South African agribusiness sector. Pretoria: Department of Agricultural Economics, Extension and Rural Development, Faculty of Natural and Agricultural Science, University of Pretoria.

Garelli, S. (2008). Competitiveness 20 years later. The IMD world competitiveness yearbook 2008. International Institute for Management Development. Lausanne, Switzerland.

Hallat, J. (2005). Relative competitiveness of South African oilseed industry. Dept. of Agric. Economics, Fac. of Natural and Agric. Sciences, Univ. of the Free State, Bloemfontein.

International Institute for Management Development (IMD). (2009). The IMD world competitiveness yearbook 2009. International Institute of Management Development. Lausanne, Switzerland. Retrieved April 16, 2009, 
from http://www.imd.ch/research/publications/wcy/wcy_book.cfm

Liwang, T. (2011). Strategy analysis to improve competitiveness of the oil palm seed industry in Indonesia. Graduate School of Management and Business, Bogor Agricultural University.

LMC International. (2009). The outlook for oleochemicals to 2020: Opportunities in a changing sector.

Muslim, C. (2006). Competitiveness analysis on the export performance of Indonesian coconut-based agroindustry. ICASEPS Working 87. Social, Economy, and Agriculture Policy Analysis Center, Research and Development Agency, Agriculture Department of Indonesia.

Ong, A. S. H., Cheah, K. Y., \& Choo, Y. M. (1989). Oleochemicals from palm oil and palm kernel oil. Elaeis, 1(1).

Pahan, I. (2011). Improving palm oil industrial cluster in Indonesia. Graduate School of Management and Business, Bogor Agricultural University.

Porter, M. E. (1990). The competitive advantage of nation. New York: Free Press.

Porter, M. E. (1998). On competition. Boston: Harvard Business School Publishing.

Rosadi, H. Y. (2002). Competitiness of pulp and paper industry in Indonesia. Technology Development and Research Center, Jakarta.

Said-Didu, M. (2000). Design on decision support system on Indonesian palm oil agroindustry development for local economy. Unpublished Thesis. Bogor Agricultural University, Bogor.

Sandaya, N. (1998). Shrimp and tuna industries in Indonesia: Strategy to increase Indonesian fisheries competitiveness for shrimp and tuna. Unpublished Thesis. Bogor Agricultural University, Bogor.

Simanjuntak. (1992). Factors affecting the competitiveness of Indonesian palm oil. Jakarta.

Sugiyanto, C. (2002). The impact of trade liberalization on the Indonesia palm oil and coconut oil market. Univ. Of Illinois, Urbana, Illinois, USA. Retrieved from http://repository.ugm.ac.id/id/eprint/19871

Sukmawati, A. (1999). Implementation study on national competitive advantage concept of milk processing industry in Indonesia. Unpublished Thesis. Bogor Agricultural University, Bogor.

Suprihatini, R. (2005). Indonesian tea export competitiveness in the world's tea market. Jurnal Agro Ekonomi, 23(1), 1-29.

Usman. (2003). Competitive advantage analysis on palm oil derivative products in Indonesia. Jakarta.

Vidyatmoko, \& Zubair. (2002). Factors affecting the competitiveness of Indonesian palm oil. Jakarta.

Wartono, B. J. (1999). Strategi improving the global competitiveness of Indonesian cashew. Unpublished Thesis. Indonesia University, Jakarta.

World Economic Forum (WEF). (2009). The global competitiveness report 2009-2010. Geneva, Switzerland: World Economic Forum. Retrieved April 16, 2010, from http://www.weforum.org/pdf/GCR09/GCR2009 2010fullreport.pdf

Zhang, X., Shen, L., Wu, Y., \& Fan, L. C. N. (2009). Competitiveness assessment for real estate enterprises in China: A model-procedure. Int. J. Strat. Prop. Manag., 13, 229-245. http://dx.doi.org/10.3846/1648-715X.2009.13.229-245

Zuhal. (2010). Knowledge \& innovation. Competitiveness strength platform. Gramedia Pustaka Utama, Jakarta.

\section{Copyrights}

Copyright for this article is retained by the author(s), with first publication rights granted to the journal.

This is an open-access article distributed under the terms and conditions of the Creative Commons Attribution license (http://creativecommons.org/licenses/by/3.0/). 